\title{
On the possibilities of solar energy usage for heating single-family houses in Poland
}

\author{
Hanna Jędrzejuk ${ }^{1, *}$ \\ ${ }^{1}$ Institute of Heat Engineering, Faculty of Power and Aeronautical Engineering, Warsaw University of \\ Technology, Nowowiejska 21/25, 00-665 Warsaw, Poland
}

\begin{abstract}
The paper presents an assessment of the possibility of using solar energy for heating a selected residential building. The influence of the thermal insulation standard of the outer casing and the air tightness of the building on technical solutions with conventional heat sources and a solar energy system was analysed. In Polish climate conditions, especially in November and December, the availability of solar energy is usually insufficient in relation to heating needs. Therefore, it is necessary to store heat when it is to be used for heating. Monthly and yearly periods of heat storage have been considered. The influence of the use of solar radiation energy on the change in the energy performance of the building and on the reduction of carbon dioxide emissions was determined. Characteristics of heating systems and devices [9] as well as generally available meteorological data [5] were used for energy calculations.
\end{abstract}

\section{Introduction}

Among many reasons for the growing importance of renewable energy in covering heating needs in housing, the following can be mentioned: increasing costs of heating using conventional (non-renewable) fuels and the tendency to reduce operating costs, striving to reduce pollutant emissions, and increasing energy independence through diversification of heat and energy sources. Constant technological progress is also essential as it makes available technical solutions that are more energy-efficient and reliable. The rationale behind hot water preparation, especially in summer, no longer raises any doubts. As far as the use of solar energy for heating is concerned, in buildings there are heat gains from solar radiation, mainly through glass partitions of the envelope, and we can say that they are obtained in a passive way. In practice, however, buildings tend not to be designed considering the use of heat gains in winter and protection against excessive profits in summer.

When estimating possible effects of active use of solar energy for heating, it should be taken into account that in Poland the energy efficiency of most residential buildings is unsatisfactory.

It is estimated that still 7.3\% (404 610) of residential buildings are characterized by an indicator of annual demand for final energy for heating, ventilation and domestic hot

*Corresponding author: Hanna.Jedrzejuk@itc.pw.edu.pl 
water preparation of more than $300 \mathrm{kWh} /\left(\mathrm{m}^{2} \mathrm{a}\right)$, and in $71.9 \%$ (2 621 650) of them this ratio exceeds $140 \mathrm{kWh} /\left(\mathrm{m}^{2}\right.$ a) $[1,4]$. Even if newly constructed buildings have definitely improved energy performance, they still account for less than $5 \%$ of all houses used [1].

\section{Simplified model}

In the heating system of a building (Figure 1), the following main components can be distinguished: a heat source, and a solar collector system with a heat storage. Variable weather conditions affect the efficiency of all the components of this system. For detailed analysis of the problem of supporting conventional heating with a solar collector system, simulation tests are necessary. On the other hand, an overall evaluation of the performance of such a system can be made using the monthly balance method, which makes it possible to use corresponding long-term energy efficiencies [6]. It should be emphasized that the efficiency of equipment, solar collectors in particular, varies each month and differs from instantaneous values. For example, the efficiency of solar collectors depends not only on irradiation, ambient temperature, heat exchange conditions, and conversion of solar radiation energy, but also on the temperature of water coming from and returning to the heat storage.

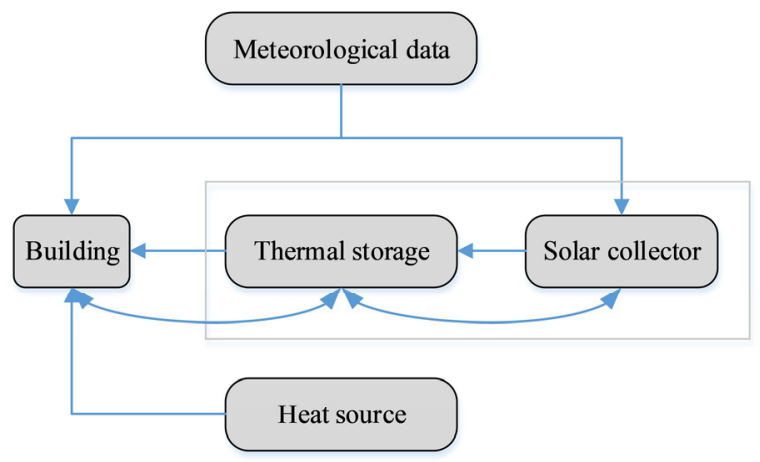

Fig. 1. Schematic diagram of a heating system with an additional heat source.

The general diagram of heat flow in a solar heating system of a building with an additional source of heat is shown in Figure 2. The energy of solar radiation is absorbed by solar collectors and undergoes photothermal conversion. In this process there are losses of available solar radiation energy and heat to the environment. When the heat carrier flows, there are also heat losses between the solar collector and the storage tank. Therefore, only a part of the heat is delivered to the storage.

Not all heat stored in the storage tank is effectively used for space heating. Further losses occur due to heat exchange with the environment and the quality of temperature control.

Figure 2 also indicates the possibility of direct heating of premises and heat losses occurring in this process, as well as heat supplied from an additional source, but the analysis of such a case requires simulation tests. 


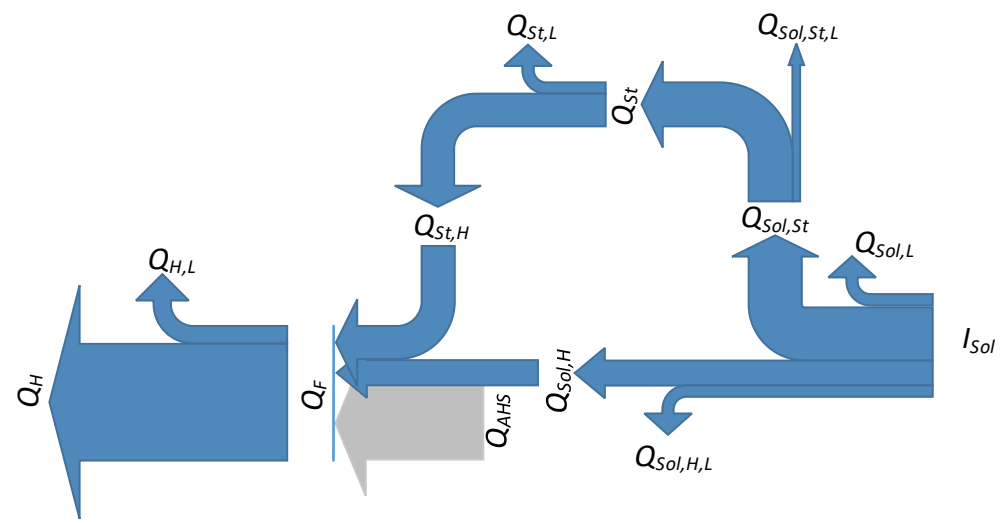

Fig. 2. Diagram of the useful heat flow in a solar heating system with an additional source of heat. $Q_{H}$ - useful heat for heating, $Q_{H, L}$ - heat losses in heating system, $Q_{F}$ - final energy needs for heating, $Q_{A H S}$ - heat from conventional heat source, $Q_{S o l, H}$ - heat for heating supported directly from solar collector system, $Q_{S o l, H, L}$ - heat losses between solar collector system and heating system, $Q_{S t, H}-$ heat for heating supported from a storage, $Q_{S t, L}$ - heat losses from the storage and between the storage and heating system, $Q_{S t}$ - effective heat accumulated in the storage, $Q_{S o l, S t, L}-$ heat losses between solar collector system and storage, $Q_{S o l, L}$ - all energy and heat losses in solar collectors, $I_{S o l}-$ global solar radiation on a solar collector surface.

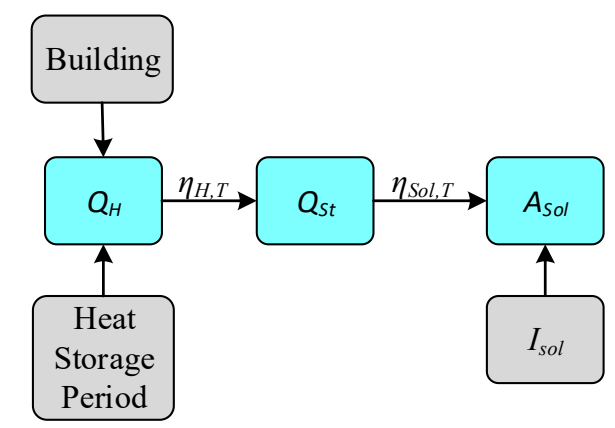

Fig. 3. Simplified diagram of the calculation.

$Q_{H}$ - useful heat for heating, $\eta_{H, T}$ - thermal efficiency of the heating system, $Q_{S t}-$ effective heat accumulated in the storage, $\eta_{S o l, T}-$ thermal efficiency of the solar collector system, $A_{\text {sol }}-$ solar collector area, $I_{S o l}$ - total solar radiation on a solar collector surface.

To estimate the storage capacity and the surface area of solar collectors, it is necessary to determine the heating needs. In the first step (Figure 3), starting from the thermal performance of the building, the monthly balance method [7] was used to calculate the amount of useful heat required for heating each month and throughout the year. Such considerations allow the verification of a monthly or annual heat storage period, but the appropriate long-term efficiencies must be determined for the period concerned. Then, after considering the heat losses within the heating system (assumed thermal efficiency $\eta_{H, 1}$ ), the final energy demand $\left(Q_{F}\right)$ is determined:

$$
Q_{F}=\frac{Q_{H}}{\eta_{H, 1}}, \mathrm{kWh} / \mathrm{a}
$$

The heat is lost due to a temperature difference between the heat carrier and the surroundings of the storage tank and during transport from the storage tank to the building. Taking thermal efficiency of this process $\left(\eta_{S t}\right)$, the amount of heat to be stored in the tank is: 


$$
Q_{S t}=\frac{Q_{H}}{\eta_{S t}}, \mathrm{kWh} / \mathrm{a}
$$

Similarly, heat losses during heat transport from the solar collectors to the storage affect the necessary amount of heat that should be obtained in solar collectors:

$$
Q_{S o l}=\frac{Q_{S t}}{\eta_{S o l, S t}}, \mathrm{kWh} / \mathrm{a},
$$

where $\eta_{S o l, S t}$ denotes thermal efficiency of this transport process.

Knowing the global solar radiation on the surface of the solar collectors $\left(I_{\text {sol }}\right)$ and the long-term efficiency $\left(\eta_{\text {Sol }}\right)$, one can determine the necessary solar collector surface area:

$$
A_{\text {Sol }}=\frac{Q_{\text {Sol }}}{I_{\text {sol }} \eta_{\text {Sol }}}, \mathrm{kWh} / \mathrm{a}
$$

Subsequently, losses along the path of heat flow from the heated space to the heat storage were integrated, and the total efficiency in this part of the heating system was expressed as:

$$
\eta_{H, T o t}=\eta_{H, 1} \eta_{S t}
$$

while the total thermal efficiency $\left(\eta_{S o l, T}\right)$ was expressed in relation to the solar energy conversion $\left(\eta_{S o l}\right)$ and the thermal efficiency of the heat storage and heat transport from solar collector to heat storage $\left(\eta_{\text {Sol,St }}\right)$ as:

$$
\eta_{\text {Sol,T }}=\eta_{\text {Sol }} \eta_{\text {Sol,St }}
$$

The determined thermal capacity of the storage tank and the assumed temperature difference between the maximum and minimum storage temperatures makes it possible to determine the required volume of the storage tank:

$$
V_{S t}=\frac{Q_{S t}}{\rho_{w} c_{w} \Delta T}, \mathrm{~m}^{3}
$$

where:

$\rho_{w}$ - average water density in the considered temperature range, $\mathrm{kg} / \mathrm{m}^{3}$,

$c_{w}$ - average specific heat of water in the considered temperature range, $\mathrm{kJ} /(\mathrm{kg} \mathrm{K})$.

\section{Case study}

To analyse the possibility of solar energy application for heating a building, a two-storey building having the shape of a rectangular cuboid was chosen.

The area of its southern and northern walls is $25 \%$ larger than that of the eastern and western ones. It was assumed that the height of the storey is $2.80 \mathrm{~m}$, and its usable area $\left(A_{f}\right)$, which was selected on the basis of statistical data [1], is $120 \mathrm{~m}^{2}$. The surface of glazed partitions is $1 / 8$ of the usable area. This assumption is in line with the minimum requirements established in the Regulation [8]. The distribution of glazed divisions is as follows: $50 \%$ of the assumed area in the southern wall and $25 \%$ in each of the eastern and western walls. The quality of thermal insulation of partitions was taken in accordance with current requirements [8] (external walls $-0.23 \mathrm{~W} /\left(\mathrm{m}^{2} \mathrm{~K}\right)$, windows $-1.10 \mathrm{~W} /\left(\mathrm{m}^{2} \mathrm{~K}\right)$, external doors $1.50 \mathrm{~W} /\left(\mathrm{m}^{2} \mathrm{~K}\right)$, roof $-0.18 \mathrm{~W} \mathrm{~m}^{-2} \mathrm{~K}^{-1}$, and ceiling above the basement $-0.25 \mathrm{~W} /\left(\mathrm{m}^{2} \mathrm{~K}\right)$. The dynamic properties of the building were defined in a simplified way, assuming that the internal thermal capacity $\left(C_{m}\right)$ in relation to the heated area $\left(C_{m} / A_{f}\right)$ is $500000 \mathrm{~J} /\left(\mathrm{K} \mathrm{m}^{2}\right)$. 
The air exchange rate in the building was assumed to be $0.51 / \mathrm{h}$. With this assumption, the ventilation air flow is $168 \mathrm{~m}^{3} / \mathrm{h}$. This value is very similar to the one required in the case of a house with a kitchen with a gas cooker and two bathrooms. In order to reduce the heat demand to warm up the ventilation air, the possibility of recovering heat from the removed air with the efficiency of $50 \%$ was taken into account. The value of unit gains was taken as $3.5 \mathrm{~W} / \mathrm{m}^{2}$. The following values of thermal efficiency of the heating system were assumed (equation 5): $100 \%, 80 \%$, and $60 \%$, and of the solar energy system (equation 6): $100 \%, 80 \%$, and $60 \%$. Of course, the efficiency of $100 \%$ is only for theoretical investigation but it serves to describe the ideal case. The angle of inclination of the collector surface with respect to the horizontal surface equal to $45^{\circ}$ and the azimuth angle of $0^{\circ}$ (south) were selected. The only available meteorological data, which are currently posted on the website of the Ministry of Investment and Development [5], were used for the calculations. The calculations were limited to a fixed heating season lasting 9 months, i.e. from 1 September to 31 May inclusive, and they were made for almost all meteorological stations (without Śnieżka and Kasprowy Wierch).

Table 1. Selected physical quantities characterising the local climate in selected meteorological stations [5].

\begin{tabular}{|l|c|c|c|c|c|}
\hline Location & $\begin{array}{c}\text { Annual } \\
\text { average } \\
\text { dry-bulb } \\
\text { temperature }\end{array}$ & $\begin{array}{c}\text { Annual average } \\
\text { dry-bulb } \\
\text { temperature in } \\
\text { the heating } \\
\text { season }\end{array}$ & $\begin{array}{c}\text { Max./min. } \\
\text { monthly dry-bulb } \\
\text { temperature } \\
\text { in the heating } \\
\text { season }\end{array}$ & $\begin{array}{c}\text { Yearly } \\
\text { irradiation on } \\
\text { the horizontal } \\
\text { surface }\end{array}$ & $\begin{array}{c}\text { Irradiation on the } \\
\text { horizontal surface: } \\
\text { in the heating season / } \\
\text { outside of the heating } \\
\text { season }\end{array}$ \\
\hline Chojnice & {$\left[{ }^{\circ} \mathrm{C}\right]$} & {$\left[{ }^{\circ} \mathrm{C}\right]$} & {$\left[{ }^{\circ} \mathrm{C} /{ }^{\circ} \mathrm{C}\right]$} & {$\left[\mathrm{kWh} /\left(\mathrm{m}^{2} \mathrm{a}\right)\right]$} & {$\left[\mathrm{kWh} /\left(\mathrm{m}^{2}\right.\right.$ period $\left.)\right]$} \\
\hline Kraków & 7.1 & 4.1 & $1.2 /-0.4$ & $\mathbf{8 0 3 . 1}$ & $\mathbf{4 6 . 1} / \mathbf{3 4 . 2}$ \\
\hline Łódź & 8.2 & 5.0 & $13.8 /-2.6$ & 1045.5 & $597.2 / 448.3$ \\
\hline Nowy Sącz & 8.2 & 5.2 & $13.5 /-1.0$ & 978.5 & $556.4 / 422.1$ \\
\hline Poznań & 8.5 & 5.6 & $13.6 / 0.5$ & 1061.5 & $616.6 / 444.9$ \\
\hline Racibórz & 8.2 & 5.0 & $13.5 /-1.8$ & 960.8 & $553.4 / 407.4$ \\
\hline Rzeszów & 7.7 & 5.8 & $14.4 /-0.8$ & $\mathbf{1 0 8 6 . 7}$ & $631.9 / 454.8$ \\
\hline Suwałki & 6.3 & 4.3 & $14.3 /-4.6$ & 1051.3 & $603.8 / 447.6$ \\
\hline Szczecin & 8.8 & 6.2 & $13.6 /-5.3$ & 837.5 & $469.7 / 367.8$ \\
\hline Świnoujście & $\mathbf{8 . 9}$ & 6.3 & $13.9 /-0.2$ & 863.0 & $488.8 / 374.2$ \\
\hline Tarnów & 9.0 & 6.3 & $14.2 /-0.8$ & 1071.6 & $599.8 / 471.7$ \\
\hline Warszawa & 8.2 & 5.1 & $12.8 /-1.2$ & 977.9 & $536.6 / 441.3$ \\
\hline Zakopane & 5.4 & 2.8 & $11.2 /-3.0$ & 1006.7 & $591.4 / 415.3$ \\
\hline
\end{tabular}

Climatic data are given in Table 1 for locations selected due to:

- the highest average temperature in the heating season (Świnoujście),

- the lowest average temperature in the heating season (Suwałki),

- the lowest average and maximum temperature in the heating season (Zakopane),

- the highest total solar irradiation on the horizontal surface outside the heating season (Tarnów),

- the highest annual solar irradiation on the horizontal surface (Racibórz), and

- the lowest annual solar irradiation on the horizontal surface outside the heating season (Chojnice).

Data for some other cities are included in the evaluation. 
Table 2. Indicator of annual useful heat demand for heating depending on the location of the test building and the quality of thermal protection.

\begin{tabular}{|c|c|c|c|c|c|}
\hline \multirow{3}{*}{ Location } & \multirow{2}{*}{\multicolumn{4}{|c|}{$\begin{array}{c}\text { Indicator of annual useful heat demand for heating, } \\
E_{U H}, \mathrm{kWh} /\left(\mathrm{m}^{2} \text { a) }\right. \\
\text { Thermal protection standard }\end{array}$}} & \multirow{3}{*}{$\begin{array}{l}\text { Change in the indicator } \\
\text { in relation to the } \\
\text { maximum value }\end{array}$} \\
\hline & & & & & \\
\hline & 2002 & 2008 & 2017 & 2020 & \\
\hline Chojnice & 160.73 & 106.16 & 57.34 & 44.31 & 3.6 \\
\hline Kraków & 137.22 & 88.44 & 45.04 & 33.47 & 4.1 \\
\hline Łódź & 137.36 & 88.36 & 45.22 & 33.98 & 4.0 \\
\hline Nowy Sącz & $\left.121.07(220.43)^{*}\right)$ & 74.57 & 34.00 & 23.65 & 5.1 \\
\hline Poznań & 140.22 & 90.91 & 46.61 & 34.81 & 4.0 \\
\hline Racibórz & 121.72 & 76.11 & 36.08 & 25.67 & 4.7 \\
\hline Rzeszów & 143.34 & 91.59 & 45.19 & 32.94 & 4.4 \\
\hline Suwałki & $\left.182.97(303.62)^{*}\right)$ & 124.87 & 71.41 & 56.56 & 3.2 \\
\hline Szczecin & 129.29 & 82.90 & 41.55 & 30.63 & 4.2 \\
\hline Świnoujście & 119.16 & 75.11 & 36.96 & 27.11 & 4.4 \\
\hline Tarnów & $\left.118.75(212.14)^{*}\right)$ & 75.61 & 38.46 & 28.60 & 4.2 \\
\hline Warszawa & 139.01 & 89.66 & 46.34 & 35.08 & 4.0 \\
\hline Zakopane & 156.11 & 97.63 & 46.10 & 32.73 & 4.8 \\
\hline
\end{tabular}

*) In brackets the value of the indicator $E_{U H}$ is given assuming 1.5 air changes per hour and without heat recovery from ventilation air

In terms of the energy performance of a building, the most unfavourable location is Suwałki, while the most advantageous Tarnów (with the lowest thermal insulation standard) and Nowy Sącz (in other cases).

\section{Possibilities of using solar energy for heating}

First, on the basis of equations (5) and (7), the required volume of heat storage was determined depending on the indicator of annual heat demand for heating (Figure 4).

For example, if $E U_{H}=20 \mathrm{kWh} /\left(\mathrm{m}^{2}\right.$ a), then at the efficiency of 0.8 , the volume of the water storage relative to the heated surface is $1.09 \mathrm{~m}^{3} / \mathrm{m}^{2}$. Therefore, if the heated area is $120 \mathrm{~m}^{2}$, the required storage volume is equal to $130.64 \mathrm{~m}^{3}$ (a cube with dimensions of approx. $5.07 \times 5.07 \times 5.07 \mathrm{~m}$ ).

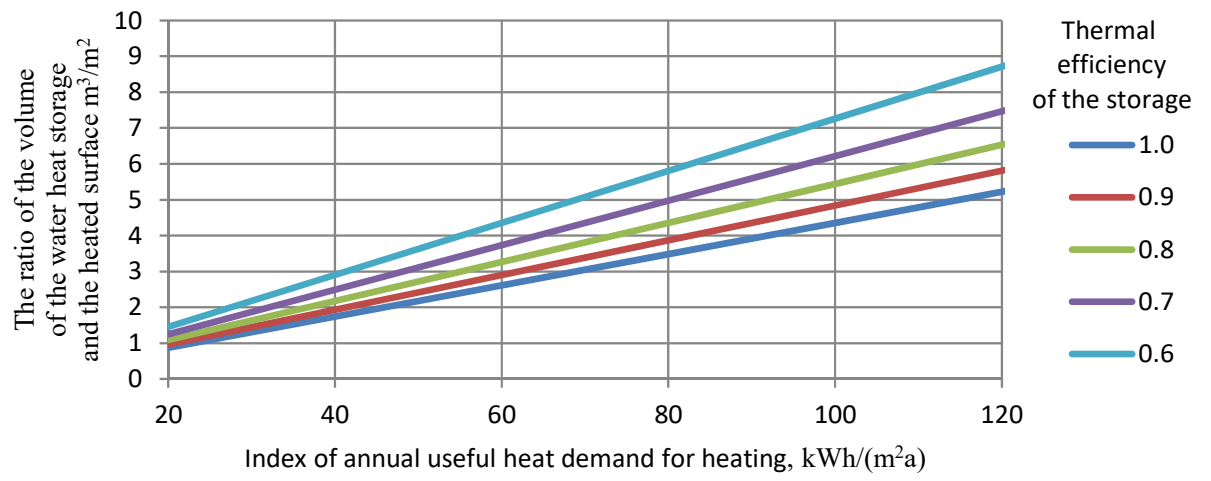

Fig. 4. The volume of the water storage as a function of the indicator of annual useful heat demand for heating $(\Delta T=20 \mathrm{~K})$. 
In the most advantageous case, i.e. Nowy Sącz, the largest energy demand for heating, when the average annual efficiency of the heating system is $80 \%$, occurs in December and amounts to $1531.1 \mathrm{kWh} /$ month (Figure 5). Assuming the long-term efficiency of the solar energy generation system $\left(\eta_{S o l, T}\right)$ of $60 \%$, collectors with an active area of $72.20 \mathrm{~m}^{2}$ are needed to meet the heating needs. However, if the heat storage operates for the whole year, the solar collector surface area of only $7.5 \mathrm{~m}^{2}$ is required. In this case, the heat of $5100.1 \mathrm{kWh} / \mathrm{a}$ should be accumulated.

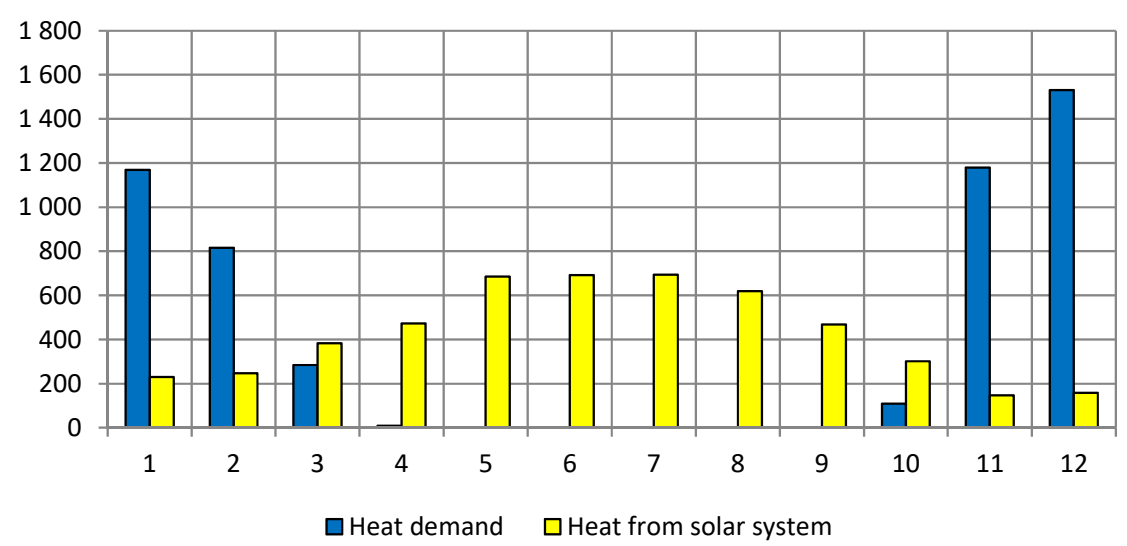

Fig. 5. Nowy Sącz. Comparison of monthly demand for final energy for heating and heat from solar collectors, $\mathrm{kWh} /$ month $\left(A_{\text {sol }}=7.50 \mathrm{~m}^{2}, \eta_{H, T}=80 \%, \eta_{\text {Sol,T }}=60 \%\right)$.

For the efficiency $\eta_{H, T}$ of $80 \%$, a house located in Suwałki will have the largest demand for heating energy (2 $766.0 \mathrm{kWh} /$ month) in January, although in December there is also a very high value of $2659.8 \mathrm{kWh} /$ month (Figure 6). Assuming long-term efficiency $\eta_{\text {Sol,T }}$ of $60 \%$, solar collectors with an active area of $168.0 \mathrm{~m}^{2}$ are needed to meet the heating needs. Due to low availability of solar energy in December, the required area is as much as $341.0 \mathrm{~m}^{2}$. In contrast, when the storage tank is used for the whole year, the area of almost $20.00 \mathrm{~m}^{2}$ is sufficient, with the heat of $10712.1 \mathrm{kWh} / \mathrm{a}$ to be stored.

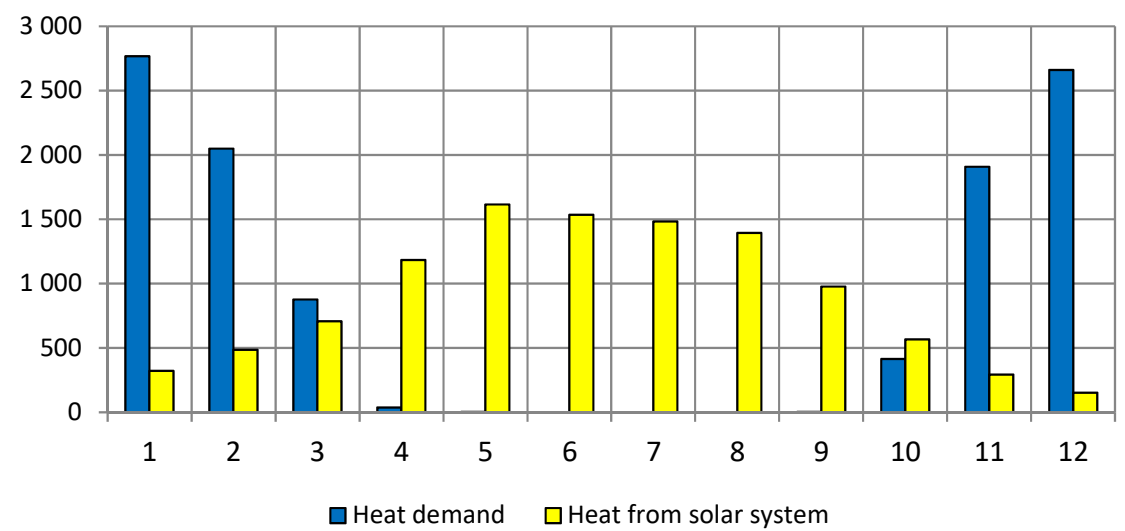

Fig. 6. Suwałki. Comparison of monthly demand for final energy for heating and heat from solar collectors, $\mathrm{kWh} / \mathrm{month}\left(A_{\text {sol }}=20.00 \mathrm{~m}^{2}, \eta_{H, T}=80 \%, \eta_{S o l, T}=60 \%\right)$. 


\section{Reduction of carbon dioxide emissions}

In order to estimate the effects of replacing conventional fuels with the clean solar energy, the methodology presented in [9] was adopted. According to the methodology, the final energy demand for auxiliary equipment is determined from the following formula:

$$
E_{e l, p o m, H}=\sum_{i} q_{e l, H, i} \cdot t_{e l, i} \cdot A_{f}, \mathrm{kWh} / \mathrm{a}
$$

where:

$q_{e l, H, i}$ - electric energy demand for the operation of the $i$-th auxiliary device in the heating system, $\mathrm{kW} / \mathrm{m}^{2}$,

$t_{e l, i}$ - operating time of the $i$-th auxiliary device in the heating system during the year, $\mathrm{h}$, $A_{f}$ - space area with adjustable air temperature (heated space), $\mathrm{m}^{2}$.

A condensing boiler was assumed to be the main heat source due to its high efficiency. Next, electric power required to drive auxiliary devices was determined taking into account: circulating pumps in the heating system with floor radiators, reservoir loading pumps, regulating and auxiliary devices necessary for the operation of a boiler and a solar energy generation system, and supply and exhaust fans in the ventilation unit with heat recovery. It was determined that the power of $1188.2 \mathrm{kWh}$ is required during the year to drive auxiliary equipment.

According to the methodology [9], the specific emission of carbon dioxide by the heating system together with the auxiliary equipment is:

$$
E_{\mathrm{CO}_{2}}=E_{\mathrm{CO}_{2}, \mathrm{H}}+E_{\mathrm{CO}_{2}, \mathrm{pom}, \mathrm{H}}
$$

where:

$E_{\mathrm{CO}_{2}, \mathrm{H}}$ - amount of $\mathrm{CO}_{2}$ emissions from the combustion of fuels through the heating system, $\mathrm{t} \mathrm{CO}_{2} / \mathrm{a}$ :

$$
E_{\mathrm{CO}_{2}, \mathrm{H}}=Q_{k, H} \cdot w_{e, H}
$$

$Q_{k, H}$ - annual energy demand for final energy supplied to the building or part of the building for the heating system, $\mathrm{kWh} / \mathrm{a}$,

$w_{e, H}-\mathrm{CO}_{2}$ emission factor depending on the type of fuel burned by the heating system, $\mathrm{t} \mathrm{CO}_{2} / \mathrm{TJ}$

$E_{\mathrm{CO}_{2} \text {,pom, } \mathrm{H}}$ - the amount of $\mathrm{CO}_{2}$ emissions from the combustion of fuels for producing electricity necessary to drive auxiliary devices in the heating system:

$$
\mathrm{E}_{\mathrm{CO}_{2}, \mathrm{pom}, \mathrm{H}}=\mathrm{E}_{\mathrm{el}, \mathrm{pom}, \mathrm{H}} \cdot \mathrm{w}_{\mathrm{el}, \mathrm{pom}, \mathrm{H}}
$$

$E_{e l, p o m, H}-$ annual demand for auxiliary secondary energy supplied to the building or part of the building for the heating system, $\mathrm{kWh} / \mathrm{a}$,

$\mathrm{w}_{\mathrm{el}, \mathrm{pom}, \mathrm{H}}-\mathrm{CO}_{2}$ emission factor depending on the method of generating electricity necessary to drive auxiliary devices in the heating system, $\mathrm{t} \mathrm{CO}_{2} / \mathrm{TJ}$.

The values of emission factors were assumed to be $[2,3]$, i.e. the emission rates of electricity produced in 2016 for end consumers of electricity equal to $781 \mathrm{~kg} \mathrm{CO}_{2} / \mathrm{MWh}$ [3], and for natural gas equal to $56.10 \mathrm{~kg} \mathrm{CO}_{2} / \mathrm{GJ}$ [2]. The results are shown in Figure 7. 


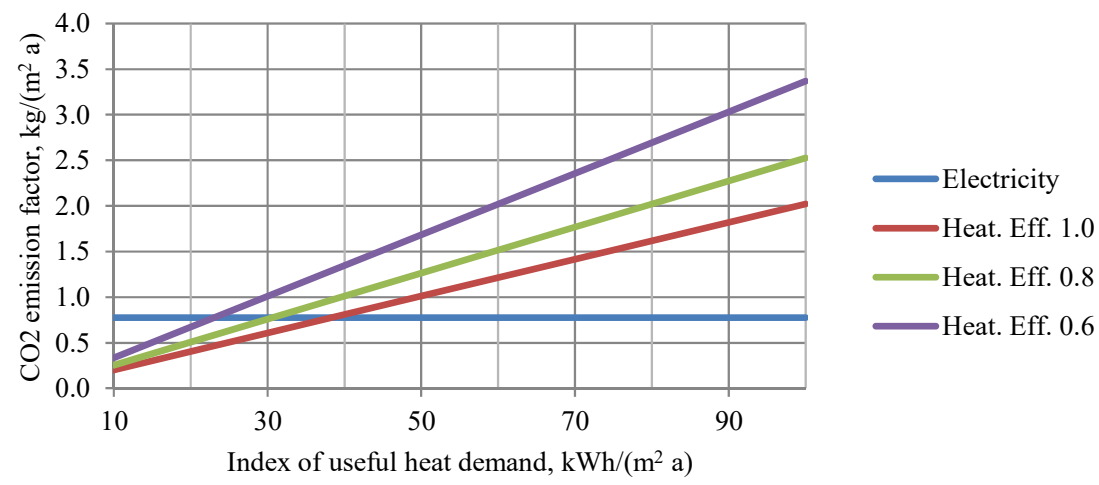

Fig. 7. Carbon dioxide emission factors depending on the indicator of annual useful energy demand for heating and the efficiency of the heating system.

The next figure (Fig. 8) presents values of the $\mathrm{CO}_{2}$ emission factor with a variable share of solar radiation energy in covering the heating needs of a building located in Suwałki with the efficiency of a heating system equal to $80 \%$.

There is a certain limit of the energy demand for heating below which the $\mathrm{CO}_{2}$ emissions will be mainly caused by the operation of auxiliary equipment, which is the case below $30 \mathrm{kWh} /\left(\mathrm{m}^{2}\right.$ a) when the heating system efficiency is $80 \%$.

With a $40 \%$ share of solar energy in the heating demand, the reduction of $\mathrm{CO}_{2}$ emissions is almost $30 \%$. However, when the needs are fully met, this reduction increases to $70 \%$.

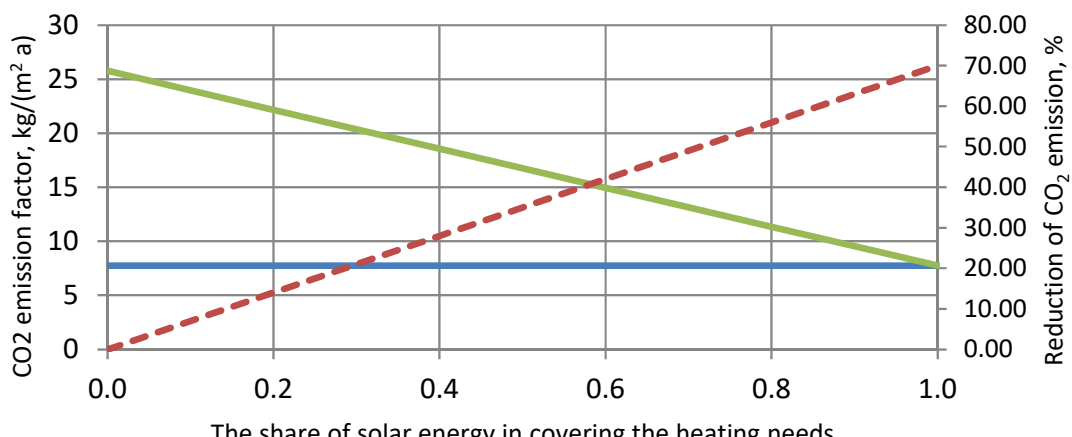

Electrical equipment Heating - - Decreasing emmission of CO2

Fig. 8. Reduction of carbon dioxide emissions due to the use of solar energy for heating the building.

\section{Conclusions}

The article presents a simplified analysis of the possibilities of using solar energy for heating a sample single-family building. It is obvious that the better the energy performance of a building is, the more possible it is to use solar energy for heating. It is observed that if the quality of thermal insulation of partitions is higher and the thermal characteristics of the ventilation system is better, then heat gains from solar radiation have greater impact on the energy performance.

Increasingly stringent requirements concerning thermal insulation of external partitions differentiate building energy characteristics depending on the local climate. 
In addition, it was indicated that:

- in Poland's climatic conditions, active solar heating without heat accumulation is not able to provide adequate temperature in rooms;

- the required volume of a water heat storage operating for the whole year may be a barrier preventing from using it;

- the surface area of solar collectors that is necessary to meet heating needs in a monthly heat storage period in the least favourable month is too large;

- the most favourable conditions for using solar energy for heating buildings occur in Nowy Sącz, while the least favourable in Suwałki;

- changing the thermal insulation standard, while maintaining the ventilation airflow required for hygienic reasons and using heat recuperation from the air removed from the rooms contributes to lowering the annual requirement for useful heat for heating between 3.2 times (Suwałki) to 5.1 times (Nowy Sącz);

- the location and local climate are important for the energy assessment of the building: the same building may have indices differing by almost 40\% (according to the 2002 requirements between Tarnów and Suwałki) or even almost $60 \%$ (according to the 2020 requirements between Tarnów and Suwałki); and

- even if the solar radiation energy fully satisfies the heating needs, the operation of auxiliary equipment results in carbon dioxide emissions to the atmosphere.

\section{References}

1. Główny Urząd Statystyczny, (Zamieszkane Budynki. Narodowy Spis Powszechny Ludności i Mieszkań 2011, Central Statistical Office. Inhabited Buildings. National Population and Housing Census 2011 in Polish, Warszawa 2013)

2. The National Centre For Emissions Management, (Wartości opałowe (WO) i wskaźniki emisji $\mathrm{CO}_{2}$ (WE) $w$ roku 2014 do raportowania $w$ ramach Systemu Handlu Uprawnieniami do Emisji za rok 2017, Calorific values (WO) and $\mathrm{CO}_{2}$ emission factors (EC) in 2014 for reporting under the Emissions Trading Scheme for 2017, in Polish Warszawa, 2016)

3. The National Centre For Emissions Management, (Wskaźniki emisyjności $\mathrm{CO}_{2}, \mathrm{SO}_{2}$, $\mathrm{NO}_{x}$, CO i pylu catkowitego dla energii elektrycznej na podstawie informacji zawartych $w$ Krajowej bazie o emisjach gazów cieplarnianych i innych substancji za 2016 rok, grudzień $2017 r$.,Emission factors for $\mathrm{CO}_{2}, \mathrm{SO}_{2}, \mathrm{NO}_{\mathrm{x}}, \mathrm{CO}$ and total dust for electricity on the basis of information contained in the National Database on greenhouse gas emissions and other substances for 2016, in Polish, December 2017)

4. S. Mańkowski (ed.)., E. Szczechowiak (ed.), (Zintegrowany system zmniejszenia eksploatacyjnej energochtonności budynków. Strategiczny projekt badawczy Tom I, część A: Uwarunkowania przekształceń w budownictwie, Integrated system for reducing the energy consumption of buildings. Strategic research project Volume I, part A: Determinants of transformations in construction, in Polish, Poznań 2013)

5. Ministerstwo Inwestycji i Rozwoju. Dane do obliczeń energetycznych budynków. (Ministry of Investment and Development. Data for energy calculations of buildings, in Polish,http://www.miir.gov.pl/strony/zadania/budownictwo/charakterystykaenergetyczna-budynkow/dane-do-obliczen-energetycznych-budynkow-1/)

6. Z. Pluta, (Stoneczne instalacje energetyczne, OWPW, (Solar energy installations, in Polish, Warszawa 2003)

7. PN-EN ISO 13790:2009 Energy performance of buildings -- Calculation of energy use for space heating and cooling. 
8. Rozporządzenie Ministra Infrastruktury z dnia 12 kwietnia 2002 r. w sprawie warunków technicznych, jakim powinny odpowiadać budynki i ich usytuowanie, Dz.U. 2015 poz. 1422 z późniejszymi zmianami (Regulation of the Minister of Infrastructure of 12 April 2002 on technical specifications for buildings and their location. Journal of Laws 2015, Item 1422, consolidated text, in Polish)

9. Rozporządzenie Ministra Infrastruktury i Rozwoju z dnia 27 lutego 2015 r. w sprawie metodologii wyznaczania charakterystyki energetycznej budynku lub części budynku oraz świadectw charakterystyki energetycznej, Dz.U. 2015, poz. 376 (Regulation of the Minister of Infrastructure and Development of 27 February 2015 on the methodology for calculating the energy performance of the building or part of the building and the preparation and design of energy performance certificates. Journal of Laws 2015, Item 376, in Polish) 